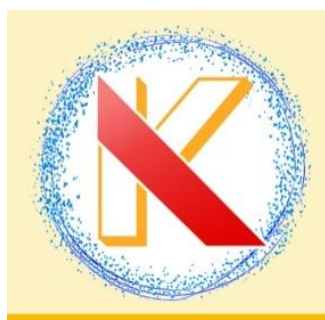

Contents list available at KOVALEN website

\title{
Pemisahan Logam Tanah Jarang dari Limbah (Tailing) Emas Poboya dengan Metode Pengendapan
}

\section{[Separation of Rare Earth Metals from Poboya Gold Waste (Tailings) by Deposition Method]}

\author{
Arianto $^{1^{*}}$, Husain Sosidi ${ }^{1}$, Prismawiryanti ${ }^{1}$, Dwi Juli Puspitasari ${ }^{1}$ \\ 1)Jurusan Kimia, Fakultas MIPA, Universitas Tadulako, Jl. Soekarno Hatta Km.9, Kampus Bumi Tadulako, Tondo Palu \\ ${ }^{\star}$ Coresponding author: rnariyanto@gmail.com
}

\begin{abstract}
Gold tailings are waste generated from gold mining activities and contain minerals and rare-earth metals (REM) that are much needed in current technological developments. This research was conducted to determine the REM content contained in Poboya gold tailings, through the destruction process using sulfuric acid and precipitation using ammonium hydroxide. The results were showed that the level of REM contained in Poboya gold tailings was 6-7\%. REM oxide content analysis performed with Scanning Electron Microscopy Energy Dispersive X-Ray Spectroscopy (SEM-EDS) obtained 6 types of REM with the main REM levels namely Terbium (Tb): $77-80 \%$ dan Lanthanum (La): $13 \%$, as well as other rare-earth metals with smaller amounts of Europium (Eu): $4-5 \%$, Cerium (Ce): $2 \%$, Neodymium (Nd): $0.02 \%$ and Gadolinium (Gd): $0.02 \%$. Poboya gold waste can be used by the community as a source of REM and used in various industries.
\end{abstract}

Keywords: Gold tailings, rare earth metals (REM), destruction, precipitation

ABSTRAK. Tailing emas merupakan limbah yang dihasilkan dari kegiatan penambangan emas dan mengandung mineral serta logam tanah jarang (LTJ) yang banyak dibutuhkan dalam perkembangan teknologi saat ini. Penelitian ini dilakukan untuk mengetahui kandungan LTJ yang terdapat dalam tailing emas Poboya melalui proses destruksi dengan menggunakan asam sulfat dan pengendapan menggunakan amonium hidroksida. Hasil penelitian menunjukkan bahwa kadar LTJ yang terkandung dalam tailing emas Poboya sebesar 6-7\%. Analisis kandungan LTJ oksida dilakukan dengan Scanning Electron Microscopy - Energy Dispersive XRay Spectroscopy (SEM-EDS) didapatkan 6 jenis LTJ dengan kadar LTJ yang utama yaitu Terbium (Tb): 77$80 \%$ dan Lantanum (La): $13 \%$, serta logam tanah jarang lain dengan jumlah yang lebih sedikit adalah Europium (Eu): 4-5\%, Serium (Ce): $2 \%$, Neodimium (Nd): 0,02\% dan Gadolinium (Gd): 0,02\%. Limbah emas Poboya dapat dimanfaatkan masyarakat sebagai sumber LTJ dan digunakan dalam berbagai industri.

Kata kunci : Tailing emas, logam tanah jarang (LTJ), destruksi, pengendapan

Riwayat artikel: Diterima 7 Oktober 2019, Disetujui 9 April 2020

Cara sitasi: Arianto., Sosidi, H., Prismawiryanti., Puspitasari, D J. (2020). Pemisahan Logam Tanah Jarang dari Limbah (Tailing) Emas Poboya dengan Metode Pengendapan. KOVALEN: Jurnal Riset Kimia, 6(1): 9-17.

DOI: https://doi.org/10.22487/kovalen.2020.v6.i1.13861

\section{LATAR BELAKANG}

Logam tanah jarang (LTJ) merupakan unsur yang sangat langka di alam. LTJ tidak pernah ditemukan sebagai unsur bebas di lapisan bumi tetapi ditemukan dalam bentuk mineralnya. Indonesia memiliki beberapa kegiatan penambangan emas aluvial dan timah alluvial yang mengandung mineral 
ikutan berupa logam tanah yang mempunyai potensi sebagai produk sampingan yang dapat memberikan nilai tambah (PSDG, 2010).

LTJ termasuk jenis mineral logam langka yang dimanfaatkan sebagai bahan baku peralatan vital militer, seperti peralatan perang dan alat pelacak serta dapat memenuhi kebutuhan produk material modern, seperti superkonduktor, laser, optik elektronik, glass, dan keramik (Soepriadi et al., 2014). Penggunaan LTJ saat ini sangat beragam, umumnya untuk industri yang menggunakan teknologi tinggi (Suganal et al., 2018).

Logam Tanah Jarang terdiri dari 17 unsur dengan rincian 15 unsur dalam kelompok lantanida dan 2 unsur lainnya yaitu Skandium dan Itrium. Unsur-unsur tanah jarang meliputi Lantanum (La), Serium (Ce), Praseodimium $(\mathrm{Pr})$, Neodimium (Nd), Prometium (Pm), Samarium (Sm), Europium (Eu), Gadolinium (Gd), Terbium (Tb), Disprosium (Dy), Holmium (Ho), Erbium (Er), Tulium (Tm), Iterbium ( $\mathrm{Yb}$ ), Lutesium (Lu), Itrium (Y) dan Skandium (Sc) (Suganal dkk., 2018). Secara umum, LTJ dibedakan menjadi 3 jenis, yaitu LTJ ringan (La, Ce, Pr, Nd, Pm, Sm, Eu), LTJ sedang (Gd, Tb, Dy, Ho), dan LTJ berat (Er, Tu, Yb, Lu) (Sastri et al., 2003). Unsur LTJ tidak ditemui sebagai logam bebas, tetapi dalam bentuk mineral karbonat, fosfat, dan halida (Gupta \& Krishnamurthy, 2004). Unsur-unsur dalam LTJ dapat didapatkan bebas dengan cara pemisahan dan pemurnian secara bertahap (Erni et al., 2000).

Proses pemisahan unsur LTJ dapat dilakukan dengan metode asam/basa (pelarutan logam dengan menggunakan asam/basa kuat), metode klorinasi (menggunakan gas klor, $\mathrm{Cl}$ ), dan metode reduksi suhu tinggi menggunakan karbon
(Callow, 1967). Metode yang palng banyak digunakan dalam proses pemisahan adalah destruksi asam atau basa (Anggraini et al., 2012). Proses destruksi biasa dilakukan dengan bantuan panas atau tekanan, serta lazim dilakukan dengan penambahan pelebur asam atau basa. Asam yang biasa digunakan untuk destruksi adalah $\mathrm{H}_{2} \mathrm{SO}_{4}, \mathrm{HNO}_{3}$, dan $\mathrm{HF}$ serta basa $\mathrm{NaOH}$ atau KOH (Harvey, 2000).

Proses pemurnian LTJ dapat dilakukan dengan berbagai cara yaitu ekstraksi, resin penukar ion dan pengendapan (Hafni et al., 2000). Proses pengendapan pada kondisi pH 10 mampu menghasilkan rekoveri LTJ hingga mendekati $100 \%$. Reagen pengendapan yang biasa digunakan adalah $\mathrm{NH}_{4} \mathrm{OH}$ dan $\mathrm{NaOH}$. Keuntungan pemakaian $\mathrm{NH}_{4} \mathrm{OH}$, penanganannya mudah dan harganya lebih murah, sedangkan pemakaian $\mathrm{NaOH}$, penanganannya lebih sulit tetapi dapat dimanfaatkan kembali hasil dari proses sebelumnya. Faktor yang sangat berpengaruh pada proses pengendapan adalah $\mathrm{pH}$, konsentrasi reagen, dan waktu pengendapan (Erni et al., 2000).

Daerah Poboya Kecamatan Mantikulore Kota Palu merupakan salah satu wilayah di Sulawesi Tengah yang memiliki potensi mineral emas sangat besar dan terdapat kegiatan penambangan emas rakyat Poboya. Area penambangan Poboya terletak di pegunungan antara Kota Palu dan Parigi dengan luas $49.460 \mathrm{Ha}$ dan lokasi yang menjadi aktivitas penambangan rakyat memiliki luas $7.120 \mathrm{Ha}$ (Dinas ESDM, 2011). Dari proses pengolahan emas tersebut terdapat limbah (tailing) yang masih mengandung mineral lain yang terbuang. Mineral tersebut diduga banyak mengandung logam tanah jarang. Tailing emas Poboya 
belum pernah dikaji sebelumnya sebagai sumber LTJ, sehingga perlu dilakukan penelitian terbaru.

\section{METODE PENELITIAN}

\section{Bahan dan Peralatan}

Bahan yang digunakan yaitu tailing emas dari tambang emas Poboya, kertas saring, akuades, asam sulfat pekat, amonium hidroksida $25 \%$, natrium hidroksida $1 \mathrm{M}$, asam klorida 0,2 M, dan hidrogen peroksida $3 \%$.

Alat yang digunakan yaitu Scanning Electron Microscopy - Energy Dispersive XRay Spectroscopy (SEM-EDS) HITACHI FLEXSEM 100, ayakan 100 mesh, pengaduk magnetik, neraca analitik Ohaus Corp. Pine Brook, pH-meter, refluks, penyaring buchner, hot plate, oven, tanur dan alat-alat gelas yang umum digunakan.

\section{Prosedur Penelitian}

\section{Pengambilan dan preparasi sampel}

Pengambilan sampel dilakukan di lokasi pengolahan emas, Kelurahan Poboya, Kecamatan Mantikulore, Kota Palu, Provinsi Sulawesi Tengah. Sampel berupa tanah yang diambil dari beberapa bak penampung akhir hasil buangan tromol. Masing-masing sampel tanah dikeringkan selama 2 hari, kemudian digerus dan diayak dengan tingkat kehalusan 100 mesh. Sebanyak 5 gram sampel dilakukan analisis mineral awal dengan menggunakan SEM-EDS untuk mengetahui kandungan LTJ yang terdapat dalam sampel tersebut.

\section{Pemisahan dan pengendapan LTJ}

Sejumlah 20 gram sampel dimasukkan ke dalam labu refluks, ditambah $40 \mathrm{~mL}$ asam sulfat, dan dipanaskan pada suhu $130-150^{\circ} \mathrm{C}$. Campuran reaksi kemudian ditambah asam sulfat $20 \%$ dan dipanaskan hingga mendidih, ditambah lagi $100 \mathrm{~mL}$ akuades dan dipanaskan kembali hingga mendidih. Hasil dekomposisi kemudian disaring dengan penyaring buchner dan dibilas dengan akuades panas sehingga diperoleh filtratnya. Filtrat hasil destruksi yang diperoleh ditambahkan $50 \mathrm{~mL}$ larutan hidrogen peroksida $3 \%$ dan amonium hidroksida $25 \%$ hingga terbentuk endapan. Endapan lalu disaring, dibilas dengan akuades panas, dan dikeringkan dalam oven pada suhu $100^{\circ} \mathrm{C}$ selama 1 jam. Selanjutnya endapan dilarutkan dengan $100 \mathrm{~mL}$ asam klorida. Dalam larutan kemudian ditambahkan natrium hidroksida $1 \mathrm{M}$ hingga mencapai kisaran $\mathrm{pH}$ 9,8-10 dan diaduk selama 3 jam. Endapan yang mengandung LTJ kemudian disaring dengan penyaring Buchner dan dikeringkan dalam oven pada suhu $100^{\circ} \mathrm{C}$ selama 1 jam. Endapan yang telah kering dikalsinasi dalam tanur pada suhu $1000^{\circ} \mathrm{C}$ selama 2 jam (Sofyatin et al., 2016). LTJ oksida hasil kalsinasi dianalisis menggunakan SEM-EDS.

\section{HASIL DAN PEMBAHASAN}

\section{Hasil Analisis Pendahuluan}

Analisis pendahuluan sampel perlu dilakukan untuk mengetahui kandungan komposisi awal dari setiap matrik yang terdapat dalam sampel tailing emas. Analisis ini dilakukan terhadap dua sampel limbah hasil pengolahan emas daerah Poboya. Tujuannya adalah sebagai perbandingan terhadap hasil pemisahan dengan harapan komposisi LTJ semakin meningkat. Sampel tailing emas dengan tingkat kehalusan 100 mesh, dianalisis menggunakan alat SEM-EDS.

Tailing emas Poboya mengandung 6 jenis unsur logam tanah jarang seperti lantanum, 
serium, neodimium, europium, gadolinium, dan terbium (Tabel 1).

Tabel 1. Komposisi sampel tailing emas

\begin{tabular}{ccc}
\hline Unsur & $\begin{array}{c}\text { Kadar } \\
\text { Sampel 1 } \\
(\%)\end{array}$ & $\begin{array}{c}\text { Kadar } \\
\text { Sampel 2 } \\
(\%)\end{array}$ \\
\hline Lantanum (La) & 0,48 & - \\
Cerium (Ce) & 0,50 & - \\
Neodimium (Nd) & 0,57 & - \\
Europium (Eu) & - & 3,43 \\
Gadolinium (Gd) & - & 3,04 \\
Terbium (Tb) & - & 21,71 \\
\hline
\end{tabular}

Menurut Junaedy (2016), sebaran mineralisasi emas yang berada di lokasi tambang emas Poboya berasosiasi dengan mineral lain seperti pirit, kalkopirit, troilite, pyrrhotites, porpiri, dan siderite. Alpinus (2010) juga menyatakan bahwa wilayah Poboya dan sekitarnya, didominasi oleh batuan kuarsa. Batuan lain yang terikut dalam proses penambangan dan tidak diambil/diolah menjadi emas adalah batuan aluminium silikat hal ini dapat dilihat dari tingginya kadar silika dan aluminium pada sampel tailing tersebut.

Morfologi taling emas di daerah Poboya diketahui dari hasil analisis dengan SEM. Hasil foto dari SEM dengan perbesaran 3000 kali (Gambar 1) terlihat bahwa tailing emas terdapat dua bentuk dimana sampel dengan butiran yang besar dan masif adalah butiran silikat dan sampel butiran lebih kecil, dengan bentuk permukaan tidak teratur menunjukkan besi serta aluminium dan terdapat unsur logam tanah jarang tanah jarang dengan kadar yang cukup tinggi, yaitu terbium ( $\mathrm{Tb}$ ) dengan kadar $21,71 \%$ kemudian unsur logam tanah jarang yang lain seperti europium (Eu) dan Gadolinium (Gd) sekitar 3\% serta unsur Lantanum (La), Serium (Ce), dan Neodimium (Nd) dibawah $1 \%$.

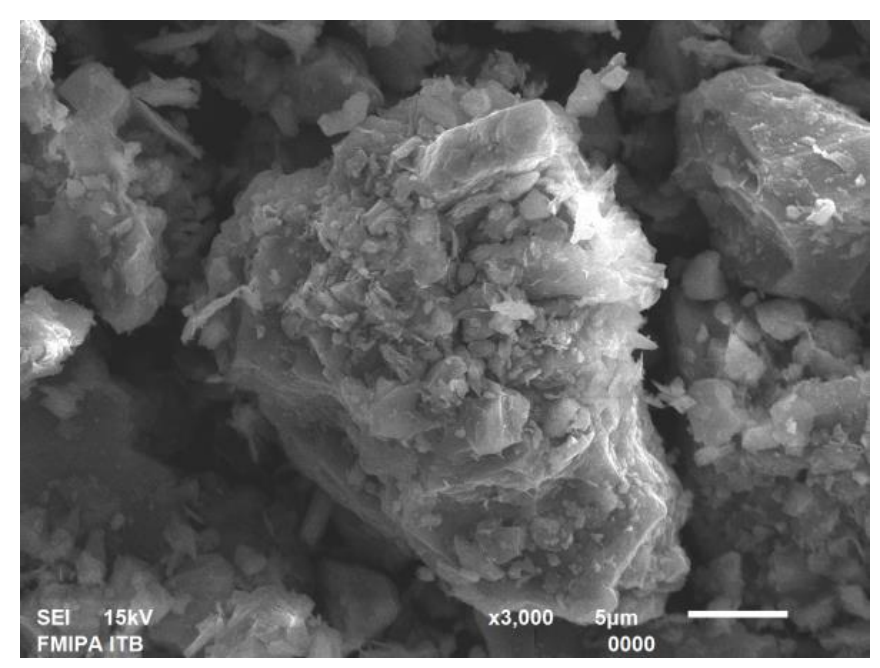

Gambar 1. Hasil foto SEM tailing emas di daerah Poboya

Menurut Sulistiyono et al. (2016), dengan melihat kedua bentuk butiran yang masif dan tidak teratur, terlihat bahwa bijih emas cenderung menempel pada silika sedangkan logam tanah jarang cenderung mengikuti unsur besi. Pada batuan berbasis silikat dan alumina, unsur thalium tidak terdeteksi dan unsur terbium dengan kadar yang cukup tinggi sekitar 6-14\%, logam tanah jarang yang lain adalah gadolinium sekitar 3-5\% dan lantanum serta serium dengan kadar kurang dari $1 \%$.

Hasil analisis EDS terhadap tailing emas di daerah Poboya, menunjukkan bahwa LTJ terletak pada 4,5-6,0 keV, dengan masing- 
masing konsentrasi unsur Lantanum (La) 0,48\%, Serium (Ce), 0,50, Neodimium ( $\mathrm{Nd}$ ) 0,57\%, Europium (Eu) 3,43\%, Gadolinium (Gd) 3,04\%, dan Terbium (Tb) 21,71\%. Selain itu, hasil spektrum EDS terdapat silika yang terletak pada 1,7 keV dengan puncak spektrum yang tinggi. Menurut Nampira et al. (2001), perbedaan energi sinar-X pada setiap unsur ini disebabkan karena perbedaan kemampuan setiap unsur untuk memindahkan elektron bagian luar ke dalam kulit yang telah ditinggalkan akibat penembakan oleh sinar-X. Unsur-unsur lantanida mempunyai konfigurasi elektron yang sama (elektron terluar menempati sub kulit orbital $6 s^{2}$ ), sedangkan kedudukan elektron yang berbeda pada orbital M (sub kulit orbital 4f).

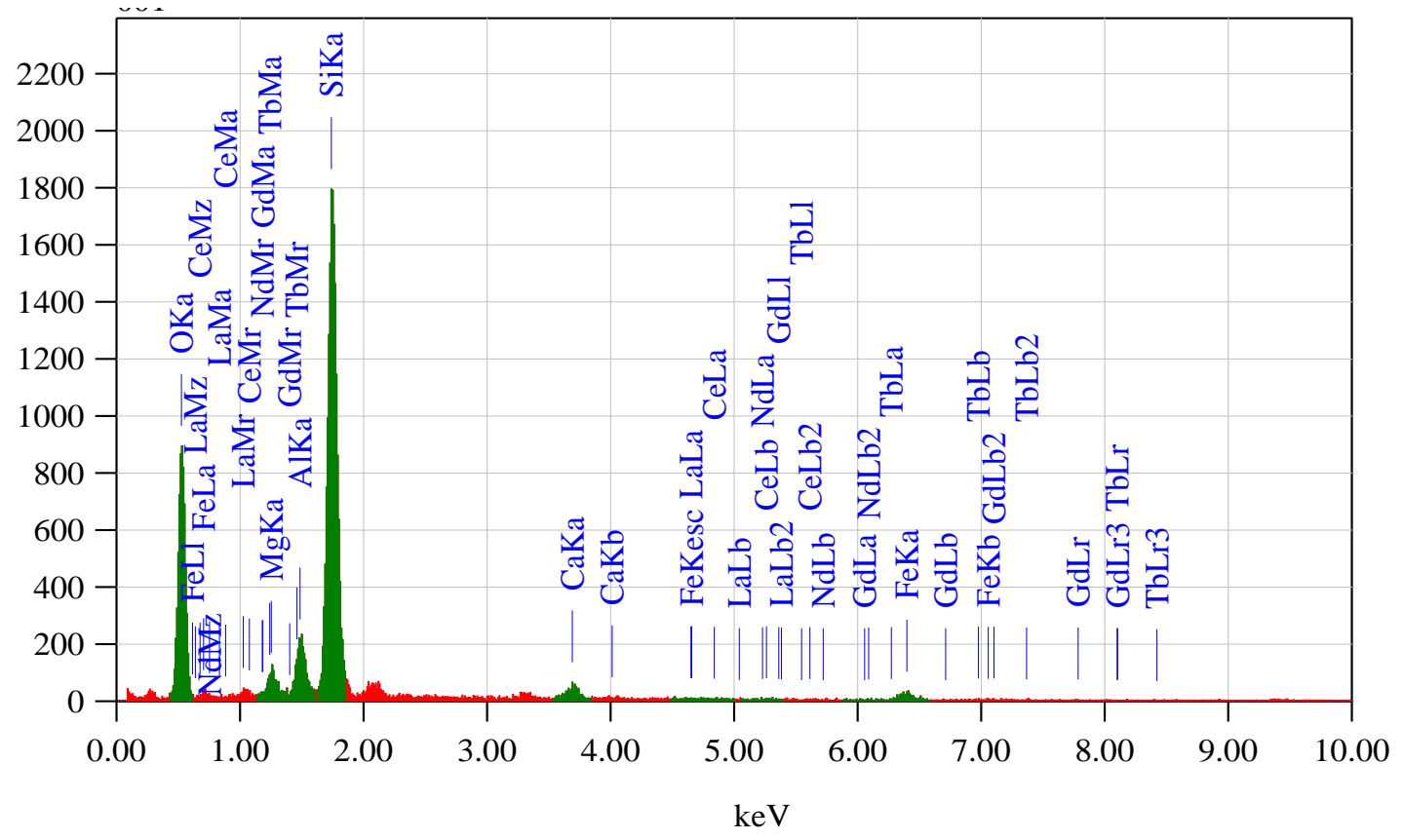

Gambar 2. Spektrum EDS dari tailing emas

\section{LTJ Oksida dari Tailing Emas}

Proses destruksi dilakukan dengan menggunakan asam sulfat pekat. Asam sulfat dapat memecah struktur dari sampel dan mengendapkan logam-logam yang bersifat refraktori seperti besi, aluminium, tembaga, dan krom sehingga tidak mengganggu pada proses analisis. Hasil destruksi berupa endapan dan filtrat, LTJ berada dalam filtrat sedangkan endapan yang berupa residu merupakan unsur pengotor seperti silikat, zirkon, dan garam-garam yang sukar larut. Penambahan hidrogen peroksida kedalam filtrat hasil destruksi bertujuan untuk mengoptimalkan jumlah kelarutan LTJ.
Hidrogen peroksida berfungsi sebagai reduktor untuk mereduksi Serium (Ce) yang memiliki dua valensi yaitu +3 dan +4 .

Pengendapan dilakukan dengan menambahkan amonium hidroksida yang bertujuan untuk memisahkan LTJ dari filtrat hasil destruksi sehingga dihasilkan endapan LTJ hidroksida, sebagaimana persamaan berikut:

$$
\begin{array}{r}
\mathrm{LTJ}_{(\mathrm{aq})}+3 \mathrm{NH}_{4} \mathrm{OH}_{(\mathrm{aq})} \rightarrow \mathrm{LTJ}(\mathrm{OH})_{3(\mathrm{~s})}+3 \mathrm{NH}_{4(\mathrm{aq})} \\
\text { Endapan LTJ hidroksida yang terbentuk }
\end{array}
$$
berupa gelatin berwarna merah disaring, dan dicuci menggunakan akuades panas untuk menghilangkan pengotor yang terlarut seperti 
sulfat dan fosfat yang menempel pada endapan. Endapan dikeringkan dalam oven untuk menghilangkan kelebihan $\mathrm{NH}_{4}{ }^{+}$. Penambahan asam klorida bertujuan untuk melarutkan pengotor dan juga unsur non LTJ seperti $\mathrm{Pb}$ dan $\mathrm{Ag}$ yang terkandung dalam endapan sehingga dihasilkan LTJ klorida, seperti persamaan berikut:

$$
\mathrm{LTJ}(\mathrm{OH})_{3(\mathrm{~s})}+3 \mathrm{HCl}_{(\mathrm{aq})} \rightarrow \mathrm{LTJCl}_{3(\mathrm{aq})}+3 \mathrm{H}_{2} \mathrm{O}_{(\mathrm{l})}
$$

Larutan LTJ klorida diendapkan kembali menggunakan $\mathrm{NaOH}$. Menurut Hafni et al. (2000), kondisi terbaik pengendapan $\mathrm{RE}(\mathrm{OH})_{3}$ pada $\mathrm{pH} 9,8$, normalitas reagen $\mathrm{NaOH} 1 \mathrm{~N}$ dan waktu pengendapan 3 jam didapatkan rekoveri $\mathrm{LTJ}_{2} \mathrm{O}_{3} 99,79 \%$ dan komposisi produk $\mathrm{RE}(\mathrm{OH})_{3} \quad 98,868 \%$. LTJ selanjutnya diendapkan sebagai hidroksida menggunakan natrium hidroksida, seperti persamaan berikut:

$\mathrm{LTJCl}_{3(\mathrm{aq})}+3 \mathrm{NaOH}_{(\mathrm{aq})} \rightarrow \mathrm{LTJ}(\mathrm{OH})_{3(\mathrm{~s})}+3 \mathrm{NaCl}_{(\mathrm{aq})}$

Endapan LTJ setelah dikeringkan dalam oven selanjutnya dikalsinasi dalam tanur sehingga didapatkan kadar LTJ dalam sampel tailing emas Poboya yaitu sebesar 6-7\%. Manurung (2013) mendapatkan total kadar endapan LTJ dari pasir monasit Bangka hanya mencapai 2,76\%. Kalsinasi merupakan proses pemanasan zat padat sampai suhu di bawah titik leleh. Kalsinasi dilakukan untuk memperoleh bentuk LTJ oksida yang stabil, seperti persamaan reaksi di bawah.

$$
2 \mathrm{LTJ}(\mathrm{OH})_{3(\mathrm{~s})} \rightarrow \mathrm{LTJ}_{2} \mathrm{O}_{3(\mathrm{~s})}+3 \mathrm{H}_{2} \mathrm{O}_{(\mathrm{s})}
$$

\section{Hasil Analisis Akhir LTJ}

Analisis akhir oksida logam tanah jarang menggunakan SEM-EDS dilakukan untuk mengetahui kandungan LTJ setelah dilakukan pemisahan. Kadar logam tanah jarang meningkat jika dibandingkan dengan sebelum pemisahan (Tabel 2).
Tabel 2. Hasil analisis akhir LTJ oksida

\begin{tabular}{ccc}
\hline Unsur & $\begin{array}{c}\text { Kadar } \\
\text { Sampel 1 } \\
(\%)\end{array}$ & $\begin{array}{c}\text { Kadar } \\
\text { Sampel 2 } \\
(\%)\end{array}$ \\
\hline Lantanum (La) & 13,04 & 13,94 \\
Cerium (Ce) & 2,47 & 2,92 \\
Neodimium (Nd) & 0,02 & 0,02 \\
Europium (Eu) & 4,40 & 5,28 \\
Gadolinium (Gd) & 0,02 & 0,02 \\
Terbium (Tb) & 80,06 & 77,82 \\
\hline
\end{tabular}

Hasil identifikasi dapat diketahui bahwa tailing/limbah hasil pengolahan emas di Poboya Kecamatan Mantikulore Kota Palu terdapat unsur logam tanah jarang yang utama yaitu Terbium ( $\mathrm{Tb}$ ) dan Lantanum (La) dan unsur logam tanah jarang lain dengan jumlah yang lebih sedikit yaitu Europium (Eu), Serium (Ce), Neodimium (Ne), serta Gadolinium (Gd) (Tabel 2).

Sulistiyono et al. (2016) melaporkan bahwa dari hasil identifikasi terhadap limbah hasil pengolahan emas di Jampang Kulon, terdapat unsur LTJ. Unsur logam tanah jarang yang utama adalah Terbium ( $\mathrm{Tb}$ ) dan Gadolinium (Gd) dan unsur lain dalam jumlah yang lebih sedikit adalah Neodimium ( $\mathrm{Nd}$ ), Lantanum (La) dan Cerium (Ce).

Morfologi dari hasil yang didapat dengan perbesaran 3000 kali menunjukkan bahwa partikel LTJ berbentuk granul yaitu berupa gumpalan partikel yang kecil dan tidak merata (Gambar 3). Ukuran dari partikel juga tidak homogen dan tingkat aglomerasi yang tinggi. Menurut Hastiawan et al. (2016), aglomerasi mengakibatkan distribusi partikel menjadi tidak homogen dan dapat menyebabkan pengotorpengotor masuk ke kisi-kisi oksida yang tidak homogen sehingga pada saat pengukuran akan terdeteksi. 


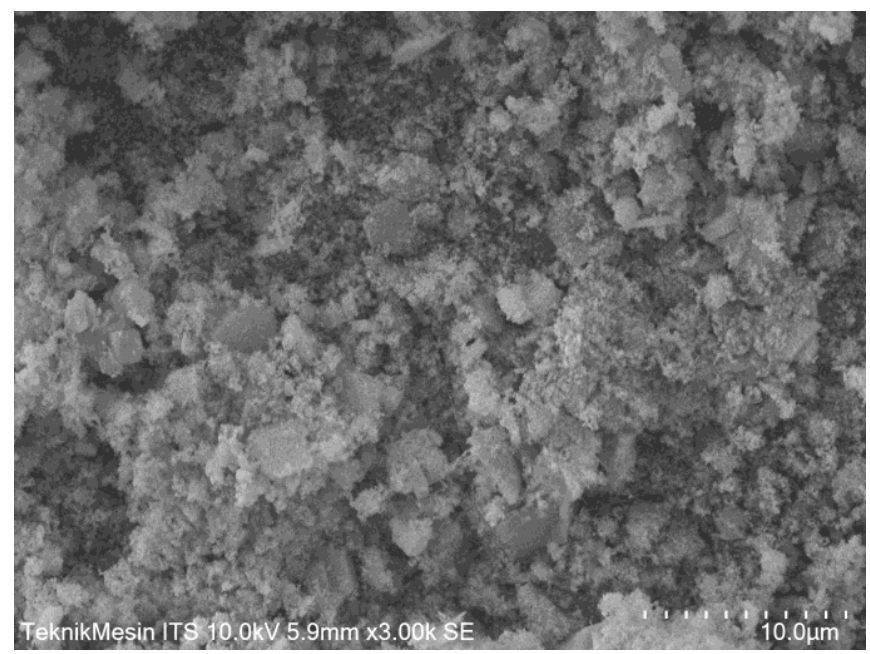

Gambar 3. Hasil foto SEM LTJ oksida

Hasil spektrum EDS LTJ oksida Neodimium (Nd) : 0,02\%, Europium (Eu) : 4menunjukkan bahwa LTJ terletak pada 4,5-6,5 5\%, Gadolinium (Gd) : 0,02\%, dan Terbium $\mathrm{keV}$, dengan masing-masing konsentrasi (Tb) : 77-80\% (Gambar 4). unsur Lantanum (La) : 13\%, Serium (Ce) : 2\%,

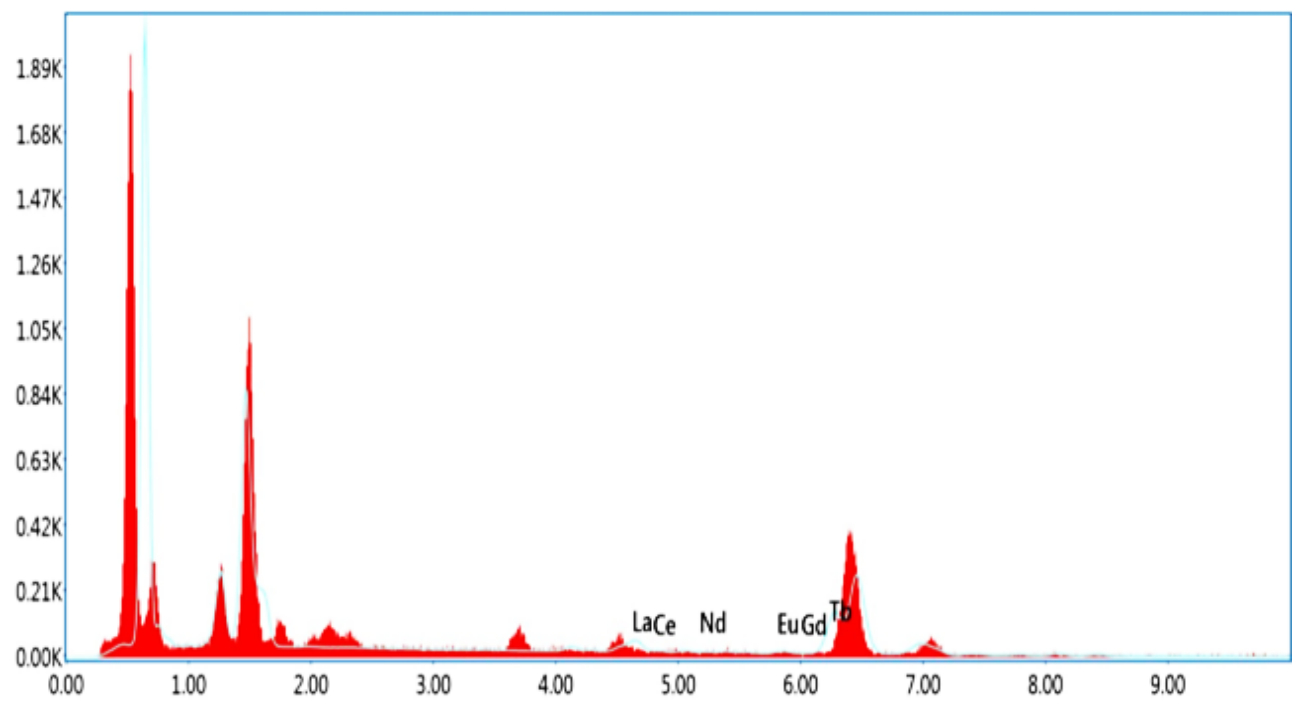

Gambar 4. Spektrum EDS dari LTJ oksida

Menurut Nampira et al. (2001), informasi tentang komposisi ini berasal dari energi yang dihasilkan oleh sinar-X. Pada spektrum yang dihasilkan oleh EDS, sumbu $X$ menunjukkan energi sinar- $X$ yang dihasilkan oleh setiap atom dalam satuan keV, sedangkan sumbu $Y$ menunjukkan intensitas sinar yang terserap sebanding dengan persen (\%) massa pada unsur yang terdapat pada sampel. Secara analisis kualitatif metode EDS ini memberikan informasi jenis unsur yang terkandung dalam bahan.

\section{KESIMPULAN}

Pada proses pemisahan logam tanah jarang dari tailing emas Poboya Kecamatan Mantikulore Kota Palu dengan metode pengendapan didapatkan kadar LTJ 6-7\%. 
Hasil identifikasi menggunakan SEM-EDS didapatkan 6 jenis LTJ yaitu Terbium (Tb): 7780\%, Lantanum (La): 13\%, Europium (Eu): 4$5 \%$, Serium (Ce): $2 \%$, Neodimium (Nd): 0,02\% dan Gadolinium (Gd): 0,02\%.

\section{DAFTAR PUSTAKA}

Alpinus. (2010). Pemetaan Lapisan Pembawa Mineral Emas di Kelurahan Poboya Kecamatan Palu Timur Propinsi Sulawesi Tengah. [Skripsi]. Universitas Tadulako, Palu.

Anggraini, M., Sumarni, Sumiarti, S, R., \& W, S. (2012). Pengendapan Unsur Tanah Jarang Hasil Digesti Monasit Bangka Menggunakan Asam Sulfat. Eksplorium, 33(2), 121-128.

Callow, R. (1967). The Industrial Chemistry of the Lanthanous, Yttrium, Thorium and Uranium. Pergamon Press, London.

Dinas ESDM. (2011). Data Potensi Sumber Daya Mineral Provinsi Sulawesi Tengah Sesuai dengan Peraturan Pemerintah Nomor 23 Tahun 2010. Dinas Energi dan Sumber Daya Mineral Provinsi Sulawesi Tengah, Palu.

Erni, R., Pudjianto, R., Zahardi, \& Susilaningtiyas. (2000). Pengolahan Bijih Uranium Asal Rirang: Pemisahan LTJ dari Hasil Digesti Basa. Prosiding Presentasi IImiah Bahan Bakar Nuklir V, 22 Februari 2000. P2TBDU dan P2BGN BATAN, Jakarta. hlm 94-101.

Gupta, C., \& Krishnamurthy, N. (2004). Extractive Metallurgy of Rare Earths. CRC Press, Washington.

Hafni, L., Faizal, R., Sugeng, W., Budi, S., Arif, S., \& Susilaningtiyas. (2000). Pengolahan Monasit dari Limbah Penambangan Timah: Pemisahan Logam Tanah Jarang (RE) dari U dan Th. Prosiding Presentasi IImiah Bahan Bakar Nuklir V, 22 Februari 2000. P2TBDU dan P2BGN BATAN, Jakarta. hlm. 54-60.

Harvey, D. (2000). Modern Analytical Chemistry. McGraw-Hill, New York.
Hastiawan, I., Firmansyah, F., Juliandri, J., Eddy, D. R., \& Noviyanti, A. R. (2016). Pemisahan Lanthanum dari Limbah Hasil Pengolahan Timah dengan Menggunakan Metode Pengendapan Bertingkat. Chimica et Natura Acta, 4(2): 93. https://doi.org/10.24198/cna.v4.n2.10678

Junaedy, M. (2016). Studi Zona Mineralisasi Emas Menggunakan Metode Magnetik di Lokasi Tambang Emas Poboya. [Skripsi]. Universitas Tadulako, Palu.

Manurung, A. R. R. (2013). Pengayaan Unsur Tanah Jarang Secara Destruksi dan Pengendapan dari Pasir Monasit Bangka. [Skrips]. Institut Pertanian Bogor, Bogor.

Nampira, Y., Amini, S., \& Kriswarini, R. (2001). Analisis Unsur Lantanida Dalam Mineral Monasit Secara Fluoresensi Sinar-X. Prosiding Presentasi IImiah Daur Bahan Bakar Nuklir VI, 7-8 November 2001. BATAN-PTBN, Jakarta. hlm 191-196.

PSDG. (2010). Potensi Logam Tanah Jarang di Indonesia. Diperoleh dari website Pusat Sumber Daya Geologi. http://psdg.geologi.esdm.go.id/index.php? option=com_content\&view=category\&id= 16\&layout=blog\&ltemid=395, diakses 12 Oktober 2019.

Sastri, V., Bunzli, J., Rao, V., Rayundu, V., \& Perumareddi, J. (2003). Modern Aspects of Rare Earths and their Complexes. Elsevier.

Soepriadi, Budiharyanto, K., \& Widi, B. (2014). Prospeksi Unsur Tanah Jarang (Rare Earth Elements) Daerah Kacang Butor dan Sekitarnya, Kecamatan Badau, Kabupaten Belitung Provinsi Bangka Belitung. Proceeding Unsur Tanah Jarang (REE) di Kab. Belitung, Prov.Bangka Belitung TA 2014. PSDG, Belitung. hIm 1-16.

Sofyatin, T., Hendrayati, D., \& Pratomo, U. (2016). Pemisahan Unsur Tanah Jarang dari Senotim dengan Metode Pengendapan Melalui Destruksi Menggunakan Akua Regia. Jurnal ICA ( Indonesian Chemia Acta ), 6(1): 25-29. 
Suganal, S., Umar, D. F., \& Mamby, H. E. (2018). Identifikasi keterdapatan unsur logam tanah jarang dalam abu batubara Pusat Listrik Tenaga Uap Ombilin, Sumatera Barat. Jurnal Teknologi Mineral Dan Batubara, 14(2): 111-125. https://doi.org/10.30556/jtmb.

Sulistiyono, E., Prasetyo, A., \& Suharyanto, A. (2016). Potensi Pemanfaatan Limbah Pengolahan Emas Proses Heap Leaching. Prosiding SEMNASTEK UMJ 2016, 8 November 2016. Fakultas Teknik Universitas Muhammadiyah, Jakarta, Jakarta. hlm 1-7. 